\title{
Pyroglutamate and Isoaspartate modified Amyloid-Beta in ageing and Alzheimer's disease
}

\author{
Maria Luisa Moro ${ }^{1 *}$, Andrew Stephen Phillips ${ }^{1}$, Katie Gaimster ${ }^{1}$, Christian Paul ${ }^{1}$, Amritpal Mudher ${ }^{2}$, \\ James A. R. Nicoll ${ }^{1}$ and Delphine Boche ${ }^{1 *}$
}

\begin{abstract}
Alzheimer's disease (AD) is the most common cause of dementia among older adults. Accumulation of amyloid- $\beta$ $(A B)$ in the brain is considered central in AD pathogenesis and its understanding crucial for developing new diagnostic and therapeutic approaches. Recent literature suggests that ageing may induce post translational modifications in $A \beta$, in the form of spontaneous amino acid modifications, which enhance its pathogenic properties, contributing to its aggregation.

In this study, we have investigated whether the isoaspartate (IsoD-A $)$ and pyroglutamate ( $p E 3-A \beta)$ modified forms of $A \beta$ are significantly associated with AD pathology or represent markers of ageing. Cerebral neocortex of 27 AD cases, 32 old controls $(O C)$ and 11 young controls $(Y C)$ was immunostained for $p E 3-A \beta$ and IsoD-A , quantified as protein load and correlated with other $A \beta$ forms and $p-T A U$. IsoD-A $\beta$ and $p E 3-A \beta$ were detected at low levels in non-demented controls, and significantly increased in $A D(p \leq 0.001)$, with a characteristic deposition of IsoD-A $\beta$ in blood vessel walls and $p E 3-A \beta$ within neurons. Both $A D$ and $O C$ showed positive associations between IsoD-A $\beta$ and $A \beta(p=0.003$ in $A D$ and $p=0.001$ in $O C$ ) and between IsOD-A $\beta$ and $p E 3-A \beta$ ( $p=0.001$ in $A D$ and $O C$ ). This last association was the only significant $p E 3-A \beta$ correlation identified in $A D$, whereas in the control cohorts $p E 3-A \beta$ also correlated with $A \beta$ and $A \beta P P$ $(p=0.001$ in $\mathrm{OC}$ and $p=0.010$ in $Y C$ ).

Our analyses suggest that IsoD-A $\beta$ accumulation starts with ageing; whereas $p E 3-A \beta$ deposition is more closely linked to $A D$. Our findings support the importance of age-related modifications of $A \beta$ in $A D$ pathogenesis.
\end{abstract}

Keywords: IsoAspartate, Pyroglutamate, Alzheimer's disease, Amyloid-beta, Ageing

\section{Introduction}

Alzheimer's disease (AD) is the most common cause of dementia in the elderly population. The molecular pathogenesis of this disease is only partially understood and the comprehension of new key aspects of its neurobiology is crucial for the future development of early diagnostic approaches and effective treatments [34]. $\mathrm{AD}$ is characterized by the intra- $[5,39]$ and extracellular accumulation in the brain of aggregated amyloid- $\beta(A \beta)$, and of hyperphosphorylated tau (p-TAU) within the neurons [32]. A $\beta$ misfolding, resulting in its aggregation into oligomers, protofibrils and fibrils, is considered crucial

\footnotetext{
* Correspondence: mluisamoro@yahoo.it; d.boche@soton.ac.uk ${ }^{1}$ Clinical Neurosciences, Clinical and Experimental Sciences Academic Unit, Faculty of Medicine, University of Southampton, Southampton, UK Full list of author information is available at the end of the article
}

in the development of $\mathrm{AD}[33]$ and synergistic with tau pathology [24]. $A \beta$ is a family of peptides generated by $\beta$ - and $\gamma$-secretase sequential cleavages of the amyloid precursor protein (APP) and currently regarded as one of the major therapeutic targets in $\mathrm{AD}$ [34].

Ageing is considered the main risk factor for $\mathrm{AD}$, but the pathway through which ageing contributes to $A \beta$ misfolding remains unclear. In particular, we still do not know whether ageing induces molecular changes in $A \beta$, driving its accumulation in the brain. Recent literature suggests that ageing may induce post-translational modifications, in particular spontaneous $A \beta$ amino acid modifications, defined as age-related modifications, which enhance its pathogenic properties [9, 21, 23, 27, 44], leading to the "Protein ageing Hypothesis of AD" [23]. It is conceivable that accumulation of age-related amino 
acid modifications could start early in the ageing process [21]. Consequently, the understanding of the relationship between age-related-modifications of $\mathrm{A} \beta$ and $\mathrm{AD}$ pathology could potentially identify new diagnostic and therapeutic approaches in early AD.

Prominent examples of these age-modified forms of $A \beta$ include isomerization (isoD-A $\beta$ ) and racemization of aspartate residues, and pyroglutamate formation at the N-terminal of $A \beta$ (pE-A $\beta$ ) [14]. IsoD- $A \beta$, similarly to the racemized form of aspartate, is the result of a chemically spontaneous and non-enzymatic reaction that introduces an additional methylene group in the peptide backbone of $A \beta$ [37]. The formation of $\mathrm{pE}-\mathrm{A} \beta$ is the consequence of a truncation at the level of a N-terminal glutamate, followed by the dehydration catalyzed by Glutaminyl Cyclase to form the cyclic pyroglutamate [11]. Evidence supports a direct role of these modifications in altering the intrinsic properties of $\mathrm{A} \beta$, as to accelerate its deposition, or to impair its clearance and degradation [23, 37]. In vitro studies have shown that IsoD-A $\beta$ was associated with accelerated $A \beta$ aggregation and fibril formation [23,36]; and known mutations, where aspartic acid of $A \beta$ is replaced by asparagine and then modified into isoD, are associated with early-onset $\mathrm{AD}$ and high levels of $\mathrm{A} \beta$ deposition $[3,6,42]$. Similar observations were reported for $\mathrm{pE}-\mathrm{A} \beta$, in particular with the modification at the glutamate in position 3 of $A \beta(p E 3-A \beta)$. It is toxic in primary culture of neurons and astrocytes [28], and its expression in mouse and Drosophila brains acts as an important source of toxicity, displaying an accelerated aggregation, enhanced synaptic toxicity, high stability and resistance to degradation $[19,28,31,38]$. Moreover, it was demonstrated that small amounts of $\mathrm{pE}-\mathrm{A} \beta$ oligomers are sufficient to trigger the aggregation of unmodified $A \beta 1-42$, leading to the formation of hypertoxic $A \beta 1-42$ oligomers [22]. Of note, passive immunization with a $\mathrm{pE}-\mathrm{A} \beta$ monoclonal antibody in APPswe/PS1 $\triangle \mathrm{E} 9$ AD mouse model, was able to lower $A \beta$ plaque burden and prevent cognitive impairment [4]. Therefore, the formation of $\mathrm{pE}$ - and IsoD- $\mathrm{A} \beta$ may have a role in the pathological process of $A \beta$ aggregation and accumulation.

In this study, we have addressed the question whether these $A \beta$ modifications are significantly associated with $\mathrm{AD}$ pathology or if they represent physiological markers of ageing, using post-mortem brain tissue from $\mathrm{AD}$ cases compared to non-neuropathological old and young controls.

\section{Materials and methods Case selection}

Seventy post-mortem cases were investigated divided among 3 cohorts as follows: $27 \mathrm{AD}$ cases, 11 young controls defined as with no significant neuropathological abnormality (YC, <63 years old) and 32 old control cases with no significant neuropathological abnormality (OC, $\geq 63$ years old), age-matched with the $\mathrm{AD}$ cohort. A summary of the cohorts is presented in Table 1 with additional information available in Additional file 1: Table S1. All AD cases had a clinical diagnosis of probable Alzheimer's disease according to NINCDS-ADRDA criteria and cases with concomitant pathology were excluded. Diagnosis was made during life by an experienced clinician and postmortem neuropathological consensus criteria for $\mathrm{AD}$ were satisfied, including Braak stage, by an experienced neuropathologist.

\section{Immunohistochemistry}

Four $\mu \mathrm{m}$ formalin-fixed paraffin-embedded sections from the inferior parietal lobule (Brodmann area 40) were retrieved from the Brain banks for all cases. Protocols for tissue fixation and processing were similar in both brain banks. In addition, the staining was performed in batches with each batch including cases from all 3 cohorts to ensure compatibility of the staining. The following primary mouse monoclonal antibodies were used: $22 \mathrm{C} 8$ against 1-12 A $\beta$ with 1,7 IsoAspartate modification (IsoD-A $\beta$ ) provided by Elan Pharmaceuticals Inc., US $[29,30] ; 337.48$ specific to $A \beta$ with pyroglutamate at the third glutamate position (pE3-A $\beta$, BioLegend, US); $4 G 8$, specific for the amino acid residues 17-24 of $A \beta$, which reacts to the abnormally processed isoforms, as well as precursor forms (A $\beta \mathrm{PP})[1,2,12]$ (BioLegend, US); 82E1, an A $\beta$ N-terminal specific antibody, which does not cross react with non- $\beta$ secretase cleaved APP (IBL, Japan, [8]); AT8, directed against the human tau, phosphorylated at Ser202 and Thr205 (p-TAU) (ThermoFisher Scientific, US) (Fig. 1 and Table 2).

Immunohistochemistry was performed using the appropriate antigen retrieval method (Table 2). Biotinylated secondary antibody (rabbit anti-mouse) was from Dako (Denmark), and normal serum and avidin-biotin complex from Vector Laboratories (UK). Bound antibody was visualized using the avidin-biotin-peroxidase complex method (Vectastain Elite $\mathrm{ABC}$ ) with 3,3'-diaminobenzidine as chromogen and $0.05 \%$ hydrogen peroxide as substrate (both from Vector Laboratories, UK). All sections were dehydrated before mounting in DePeX (VWR International, UK). Sections incubated in the absence of the primary antibody were included as negative controls.

Table 1 Summary of the AD, old and young cohorts

\begin{tabular}{llllll}
\hline Case & Gender & $\begin{array}{l}\text { Age at } \\
\text { death }\end{array}$ & $\begin{array}{l}\text { APOE } \\
\text { status }\end{array}$ & $\begin{array}{l}\text { Braak } \\
\text { stage }\end{array}$ & $\begin{array}{l}\text { Dementia } \\
\text { duration (years) }\end{array}$ \\
\hline AD & $15 F: 12 M$ & $63-88$ & $20 \varepsilon 4+: 5 \varepsilon 4-$ & IV-VI & $3-17$ \\
OC $(n=32)$ & $16 F: 16 M$ & $64-97$ & $5 \varepsilon 4+: 27 \varepsilon 4-$ & $0-I I I$ & $n / a$ \\
YC $(n=11)$ & $6 F: 5 M$ & $26-62$ & $n / d$ & $n / d$ & $n / a$ \\
\hline
\end{tabular}

n/a non-applicable

$n / d$ non-determined 
REGIONS Of APP RECOGNIZED BY THE ANTIBODIES USED IN THIS STUDY

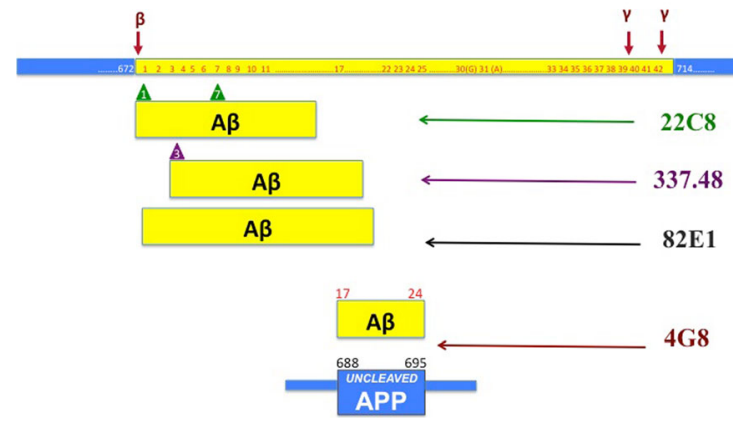

Fig. 1 Regions of APP recognized by the antibodies used in this study. Top of the figure: Illustration of APP. A $\beta$ region is labelled in yellow and $\beta$ and $\gamma$-secretase cleavage sites are indicated in red. Bottom of the figure: Illustration of the A $\beta$ and APP regions recognized by $22 \mathrm{C} 8$, $337.48,82 \mathrm{E} 1,4 \mathrm{G} 8$ clones. The positions of IsoD- and pE3-A $\beta$ modifications recognized, respectively by clones $22 \mathrm{C} 8$ and 337.48 , are indicated with triangles

\section{IsoD-A $\beta$ and $p E 3-A \beta$ quantification}

Quantification was performed blind to the experimental group and identity of the cases. For each antibody and case, 30 images of cortical grey matter were taken using a $\times 20$ objective lens, in a zigzag sequence in order to ensure that all cortical layers were represented in the quantification. The sampling pattern between all cases was consistent, starting at the depth of the sulcus and progressing up the sulcal wall to the gyral surface. The acquired images were analysed using ImageJ version 1.49 software (developed by Wayne Rasband NIH, US) with a threshold applied to the image to select and measure the total amount of specific immunostaining. The same threshold setting was maintained for all images of all cases stained for the same antibody, and the area fraction of the measure function provided the proportion (\%) of the stained area related to the total area of the image (expressed as protein load).

\section{Semi quantitative assessment}

Immunodetection for Iso-DA $\beta$ and $\mathrm{pE} 3-\mathrm{A} \beta$ was assessed as present or absent according to the staining being defined as: intraneuronal deposits [5], dense-core plaques, diffuse plaques and vessel wall deposits (i.e. cerebral amyloid angiopathy: CAA) [35]. The staining was independently reviewed by two operators.

\section{Statistical analysis}

To compare the protein load of the different $A \beta$ forms and p-TAU between the cohorts, the normality of each marker was assessed through examination of quantile-quantile plots (not shown). As the data were non-parametric, the Kruskal-Wallis test was performed for comparison among the three groups for each marker. To assess whether the presence of $\mathrm{pE} 3-\mathrm{A} \beta$ and IsoD-A $\beta$ immunostaining in intraneuronal deposits, dense-core plaques, diffuse plaques and CAA differed significantly between $\mathrm{AD}$ and $\mathrm{OC}$ and $\mathrm{OC}$ and YC, the Fisher's Exact Test was used.

To investigate the relationship of isoD-A $\beta$ and $\mathrm{pE} 3-\mathrm{A} \beta$ with the other $A \beta$ forms and $p$-TAU, correlations were performed using the Pearson or Spearman correlation coefficients, as determined by the normality of the markers. The threshold for statistical significance was set at 5\% for intergroup comparisons and Fisher's test and 1\% for correlations, as determined by the use of SPSS 21.0 (IBM, US).

\section{Results}

\section{Quantification of IsoD and $p E 3-A \beta$}

The quantification of IsoD-A $\beta$, independently of the location of the staining, revealed that IsoD-A $\beta$ load was significantly higher in AD compared to OC $(p<0.001)$ and $\mathrm{AD}$ vs $\mathrm{YC}(p=0.001)$ cohorts. No significant difference was identified between OC and YC groups (Fig. 2a).

Similarly, the pE3-A $\beta$ load was significantly higher in $\mathrm{AD}$ vs $\mathrm{OC}(p=0.001)$ and $\mathrm{AD}$ vs $\mathrm{YC}(p<0.001)$ cases; while no significant difference was found between $\mathrm{OC}$ and YC groups (Fig. 2e).

\section{IsoD-A $\beta$ and $p E 3-A \beta$ immunodetection and locations}

IsoD- $A \beta$ and $p E 3-A \beta$ immunostaining was observed in the commonly identified $A \beta$ locations in the brain: intraneuronal deposits, diffuse deposits, dense-core plaques, and CAA (Fig. 3a-d and f-i). However significant differences were observed between $\mathrm{OC}$ and $\mathrm{AD}$ regarding the

Table 2 Antibodies and immunohistochemistry conditions

\begin{tabular}{|c|c|c|c|c|c|c|}
\hline Clone & Specificity & Company & $\begin{array}{l}\text { Modified amino } \\
\text { acid }\end{array}$ & $\begin{array}{l}\text { Antigen } \\
\text { Abbreviation }\end{array}$ & Dilution & Antigen retrieval method \\
\hline $22 \mathrm{C} 8$ & IsoAspartate $A \beta$ & Elan Pharmaceuticals & Aspartate in position 1,7 & IsoD-A $\beta$ & $1: 10,000$ & Formic acid $80 \%$ for $30 \mathrm{~min}$ \\
\hline 337.48 & pyroglutamate $A \beta$ & BioLegend & Glutamate in position 3 & $\mathrm{pE} 3-\mathrm{A} \beta$ & 1:100 & $\begin{array}{l}\text { Formic acid } 100 \% \text { for } 3 \text { min + EDTA } \\
\text { buffer and microwave }\end{array}$ \\
\hline $4 \mathrm{G} 8$ & $A \beta$ and $A P P$ & BioLegend & $\mathrm{n} / \mathrm{a}$ & $\mathrm{A} \beta \mathrm{PP}$ & $1: 2000$ & Formic acid $80 \%$ for $30 \mathrm{~min}$ \\
\hline $82 \mathrm{E} 1$ & N-terminus end specific & $\mathrm{IBL}$ & $\mathrm{n} / \mathrm{a}$ & $A \beta$ & $1: 100$ & Formic acid $80 \%$ for $30 \mathrm{~min}$ \\
\hline AT8 & Phosphorylated tau & ThermoFisher Scientific & Ser202 and Thr205 & $\mathrm{p}-\mathrm{TAU}$ & $1: 500$ & $\begin{array}{l}\text { Sodium citrate buffer and pressure } \\
\text { cooker }\end{array}$ \\
\hline
\end{tabular}



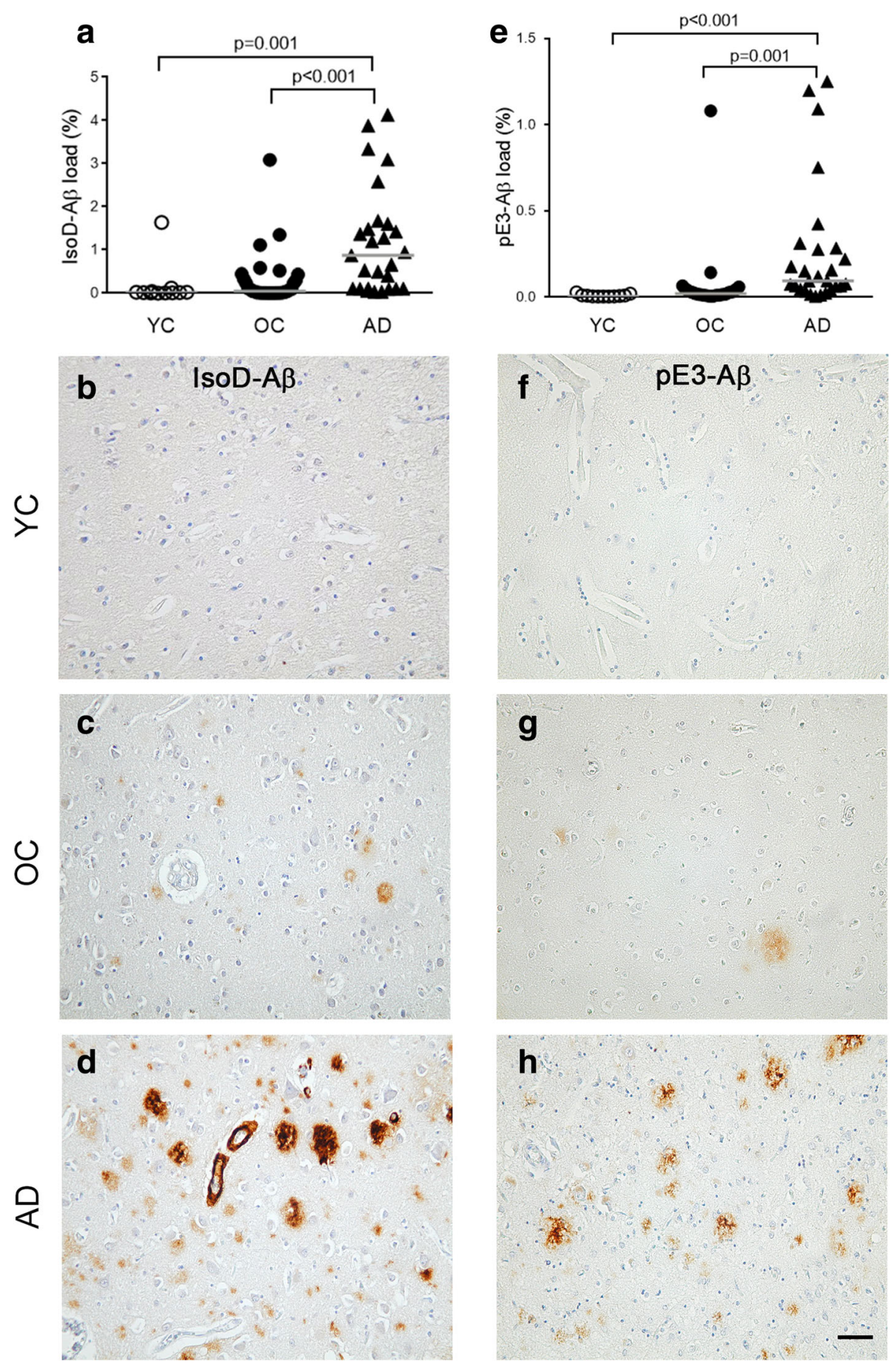

Fig. 2 Quantification of IsoD-A 3 and $p E 3-A \beta$ loads. Both IsoD-A $(\mathbf{a})$ and $p E 3-A \beta$ (e) loads are significantly higher in the $A D$ cases than in the $O C$ and $Y C$ groups. Illustrations of immunostaining for IsoD-A $\beta$ (b-d) and $p E 3-A \beta(\mathbf{f}-\mathbf{h})$ in the 3 cohorts. Scale bar $=50 \mu \mathrm{m}$

presence of some of these neuropathological features (Fig. 3e-j).

Overall, the comparison between $\mathrm{AD}$ and $\mathrm{OC}$ cases revealed that IsoD-A $\beta$ immunostaining in core plaques and CAA was significantly more frequent in the $\mathrm{AD}$ vs $\mathrm{OC}$ cases (core plaques: $\mathrm{AD}=96 \%$ vs $\mathrm{OC}=44 \%, p<0.0001$;
CAA: $\mathrm{AD}=63 \%$ vs $\mathrm{OC}=28 \%, p=0.009$ ) (Fig. 3e). IsoD-A $\beta$ intraneuronal deposits were also significantly more present in $\mathrm{AD}$ than $\mathrm{OC}$; however this feature was limited to only a minority of $\mathrm{AD}$ cases $(\mathrm{AD}=18 \%$; $\mathrm{OC}=0 \%, p=0.039)$. No significant difference was observed instead in relation to IsoD-A $\beta$ stained diffuse deposits $(p=0.118)$ (Fig. 3e). 


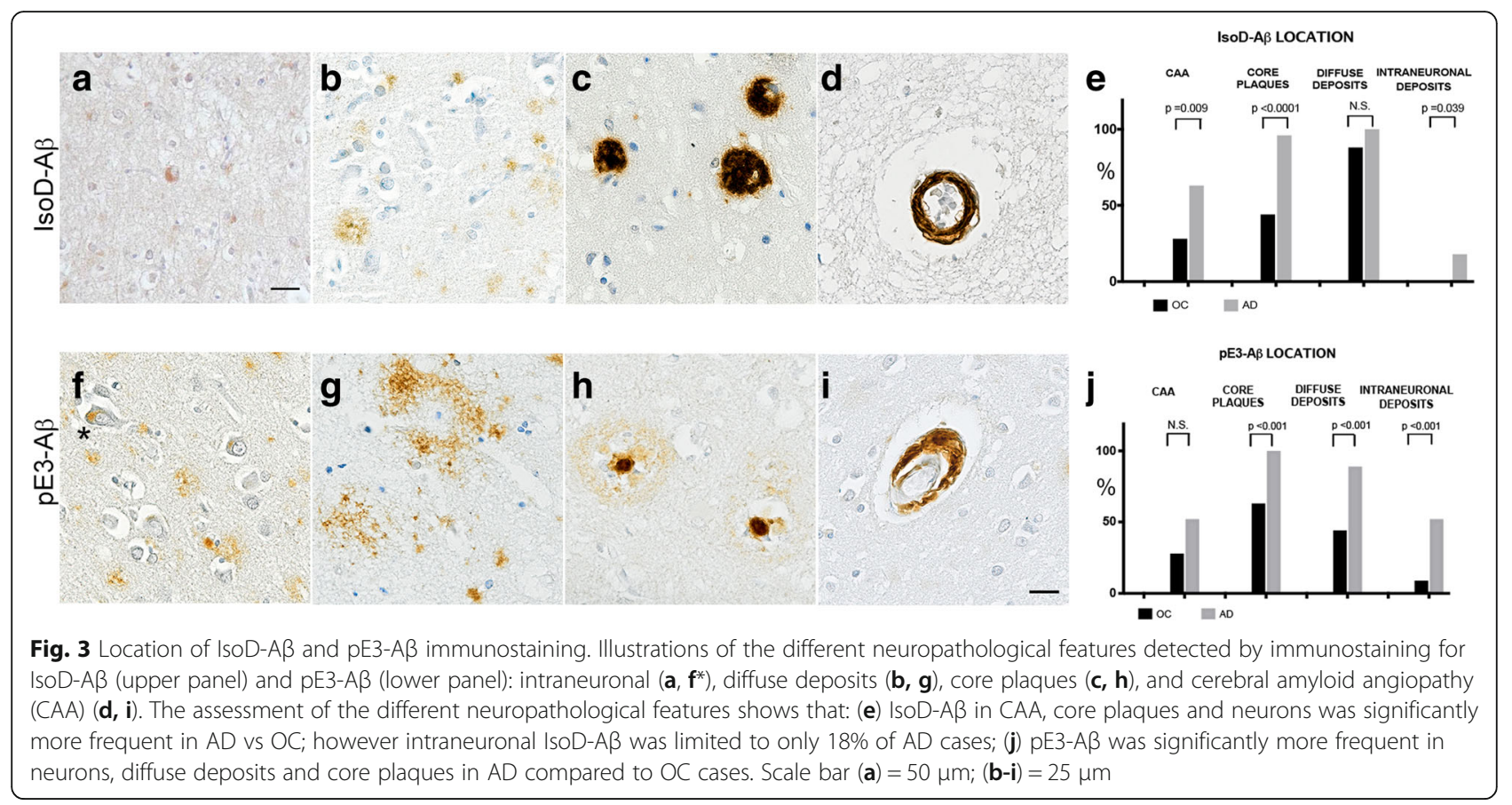

No IsoD-A $\beta$ staining was identified in YC (Fig. 5j), with the exception of 2 cases among the oldest, who were 59 and 62 years old and had some diffuse and core plaques (Fig. 5l).

pE3-A $\beta$ immunostaining was significantly more present in $\mathrm{AD}$ vs $\mathrm{OC}$ cases in intraneuronal deposits $(\mathrm{AD}=52 \%$ vs $\mathrm{OC}=9 \%, p<0.001)$; in diffuse plaques $(\mathrm{AD}=89 \%$ vs $\mathrm{OC}=$ $44 \%, p<0.001)$; and core plaques $(\mathrm{AD}=100 \%$ vs $\mathrm{OC}=$ $63 \%, p<0.001$ ) (Fig. 3j). No significant difference was observed instead in relation to $\mathrm{PE}-\mathrm{A} \beta \mathrm{CAA}(p=0.065)$.

pE3-A $\beta$ was negative in the majority of $Y C$ (Fig. $5 k$ ). Only two YC cases, the same cases which have sparse isoD-A $\beta$ deposits, also had sparse $\mathrm{pE} 3-\mathrm{A} \beta$-positive immunostaining mainly as diffuse plaques, with the case aged 62 also having few core plaques (Fig. 5m).

\section{Relationship between IsoD, $\mathrm{pE} 3-\mathrm{A} \beta$ and hallmarks of $A D$} Correlations were performed in the 3 cohorts between IsoD and $\mathrm{pE} 3-\mathrm{A} \beta$ loads each other, and respectively, with A $\beta P P$ (clone 4G8), A $\beta$ (clone 82E1), and p-TAU (AT8 antibody). All analyses are presented in Table 3 and Fig. 4 and the representative pictures in Fig. 5. In the $\mathrm{AD}$ group, two significant positive correlations were found for IsoD-A $\beta$ with pE3-A $\beta$ ( $\rho=0.582, p=0.001)$ and $A \beta$ $(\rho=0.545, p=0.003)$. In the OC cohort, significant positive associations were identified for IsoD-A $\beta$ with $p E 3-A \beta$ $(\rho=0.557, \mathrm{p}=0.001), \mathrm{A} \beta(\rho=0.578, \mathrm{p}=0.001)$ and $\mathrm{A} \beta \mathrm{PP}$ $(\rho=0.591, p<0.001)$.

For $\mathrm{pE} 3-\mathrm{A} \beta$ in $\mathrm{OC}$ cohort, in addition to the correlation identified with IsoD-A $\beta$, there were positive significant associations with $\mathrm{A} \beta(\rho=0.609, \mathrm{p}<0.001)$ and $\mathrm{A} \beta \mathrm{PP}(\rho=$ $0.570, p=0.001$ ). Within the YC group, a positive correlation was observed between A $\beta$ PP and pE3-A $\beta$ load $(\rho=$ $0.736, p=0.010$ ).

\section{Discussion}

In this study, we have investigated two post-translational modifications of $A \beta$, IsoD- $A \beta$ and $p E 3-A \beta$, normally defined as age-related modifications $[11,21,25]$, and explore whether their accumulation is significantly increased in $\mathrm{AD}$ patients compared with age-matched controls and

Table 3 Results of correlation analyses within the 3 cohorts

\begin{tabular}{|c|c|c|c|c|c|c|c|c|c|c|c|c|}
\hline & \multicolumn{4}{|c|}{ AD cases } & \multicolumn{4}{|c|}{ OC cases } & \multicolumn{4}{|c|}{ YC cases } \\
\hline & $\mathrm{pE3}-\mathrm{A} \beta$ & $\mathrm{A} \beta \mathrm{PP}$ & $A \beta$ & $p-T A U$ & $p E 3-A \beta$ & AßPP & $A \beta$ & $p-T A U$ & $p E 3-A \beta$ & $\mathrm{A} \beta \mathrm{PP}$ & $A \beta$ & p-TAU \\
\hline \multirow[t]{2}{*}{ IsoD-A $\beta$} & $\rho=0.582$ & $\rho=-0.026$ & $\rho=0.545$ & $\rho=0.336$ & $\rho=0.557$ & $\rho=0.591$ & $\rho=0.578$ & $\rho=0.289$ & $\rho=0.097$ & $\rho=0.145$ & $\rho=0.247$ & $\rho=0.382$ \\
\hline & $p=0.001$ & $p=0.897$ & $p=0.003$ & $p=0.086$ & $p=0.001$ & $p<0.001$ & $p=0.001$ & $p=0.115$ & $p=0.778$ & $p=0.670$ & $p=0.465$ & $p=0.246$ \\
\hline \multirow[t]{2}{*}{$\mathrm{pE} 3-\mathrm{A} \beta$} & & $\rho=0.119$ & $\rho=0.098$ & $\rho=0.389$ & & $\rho=0.570$ & $\rho=0.609$ & $\rho=0.380$ & & $\rho=0.736$ & $\rho=0.663$ & $\rho=0.107$ \\
\hline & & $p=0.554$ & $p=0.628$ & $p=0.045$ & & $p=0.001$ & $p<0.001$ & $p=0.038$ & & $p=0.010$ & $p=0.026$ & $p=0.755$ \\
\hline
\end{tabular}

bold $^{* *}$ correlation significant at the 0.01 level (2-tailed)

italic: Pearson's $\rho$ and $p$-value

non-italic: Spearman's $\rho$ and $p$-value 

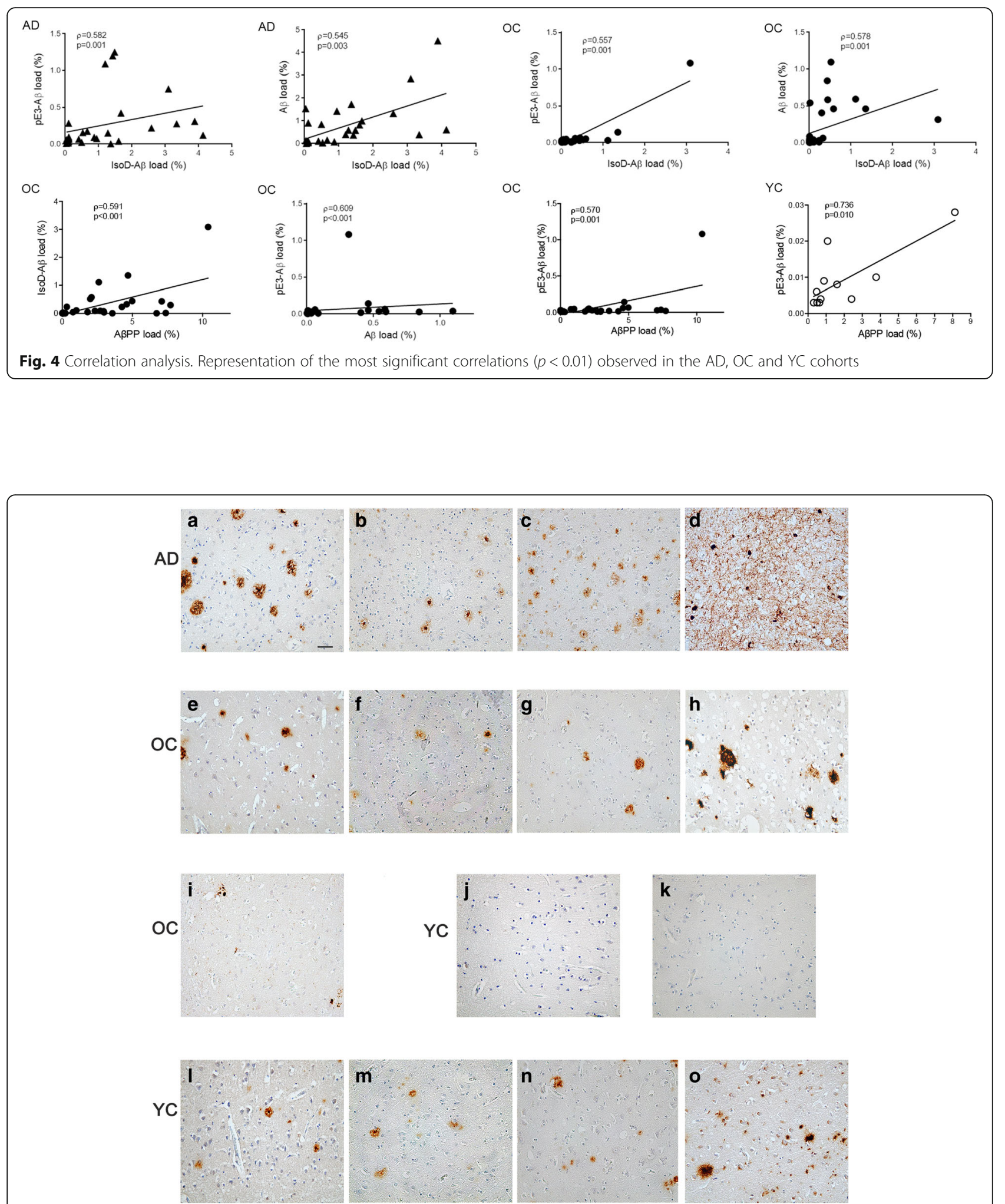

Fig. 5 Pictures of IsoD-A $, p E-A \beta, A \beta, A \beta P P$ and $p-T A U$ in $A D, O C$, and $Y C$. Representative pictures of IsoD-AB (a), $p E 3-A \beta$ (b), $A \beta$ (c), $p-T A U$ (d) staining of $A D$ cases, the significant correlations of which are described in Table 3. Representative pictures of IsoD-A $(\mathbf{e}), p E 3-A \beta(\mathbf{f}), A \beta(\mathbf{g}), A \beta P P$ (h) and p-TAU (i) staining of OC cases, the significant correlations of which are described in Table 3. IsoD-A $\beta$ (j) and pE3-A $(\mathbf{k})$, as well as $A \beta$, ABPP and p-TAU staining were negative in the majority of YC. Only in two YC cases, IsoD-A $\beta$ (I), pE3-A $(\mathbf{m}), A \beta(\mathbf{n}), A \beta P P(\mathbf{o})$ deposits were detectable. Scale bar $=50 \mu \mathrm{m}$ 
younger controls. Our findings show that both IsoD-A $\beta$ and $\mathrm{pE} 3-\mathrm{A} \beta$ can be detected at a low level in non-demented age-matched controls but both are at significantly higher levels in AD.

It is possible that these modified forms of $A \beta$ start to form and aggregate years before other molecular lesions and symptoms of disease clearly appear. Indeed pE3-A $\beta$ has been detected in the past not only in plaques but also in dispersible and soluble $\mathrm{A} \beta$ aggregates outside the plaques and described in pathologically preclinical $\mathrm{AD}$ cases [26]. Consequently in our study, some of nondemented age-matched controls might have actually died after IsoD- $A \beta$ and $p E 3-A \beta$ accumulation in the brain had started, but before the formation of a significant $A \beta$ burden.

The higher level of IsoD-A $\beta$ in $\mathrm{AD}$ may be explained by the properties of the amino acid of $A \beta$. There is evidence that IsoD forms most easily at sequences in which the side chain of the C-flanking amino acid is relatively small and hydrophilic [36]. The most favourable C-flanking amino acids are Glycine (G), Serine (S), and Histidine (H). The $A \beta$ sequence has $S$ and $G$ residues at the $C$-term of aspartate 7 (D7), rendering this residue most likely to be spontaneously transformed to IsoD with ageing. The other aspartate residue analysed, D1, is the first amino acid of the $\mathrm{A} \beta$ sequence, which is also the $\beta$-secretase site of APP. D1 does not have $\mathrm{C}$-term residues favourable to spontaneous isomerization. However, its isomerization in $\mathrm{AD}$ can be driven by other chemical conditions, e.g. oxidative stress and production of radicals [18] as demonstrated for Dracemization $[13,40]$, occurring through the same chemical intermediate of D-isomerization [21]. Therefore, it is reasonable to hypothesize that in $\mathrm{AD}$, IsoD- $\mathrm{A} \beta$ accumulates at a significantly higher level than during ageing due to faster isomerization of D7 or to a possible additional modification of D1; processes that are likely not to be mutually exclusive.

The increased $\mathrm{pE} 3-\mathrm{A} \beta$ in $\mathrm{AD}$ may be explained by increased expression of Glutaminyl cyclase (QC), the enzyme that catalyses the conversion of glutamate into pyroglutamate. $\mathrm{QC}$ was found in the cortex of $\mathrm{AD}$ patients [20] and its levels correlated with insoluble pE3-A $\beta$ aggregates, and not with unmodified $A \beta$ peptides. Noteworthy, in the same patients, the insoluble pE3-A $\beta$ correlated with the cognitive decline better than elevated level of unmodified A $\beta$ [20].

As expected, in our study, the majority of $Y C$ cases did not have IsoD- or $\mathrm{pE} 3-\mathrm{A} \beta$ forms. Of note, the only cases that had some immunostaining were among the oldest, aged 59 and 62 years, and thus close to the old control group.

Similar observations were reported in a study focused on brain tissues of cases with Down Syndrome (DS). Trisomy 21 is associated with the progressive development of AD neuropathology as observed in DS people in their forties. A study reported that deposits containing $\mathrm{pE} 3-\mathrm{A} \beta$ were not detectable in DS cases under 27 years old, while they were present in older cases [16].

Interestingly, our assessment of different features of $\mathrm{A} \beta$ deposits shows that the differences between $\mathrm{AD}$ and controls are not only quantitative, but also related to the specific compartments of brain parenchyma and vasculature where IsoD- $A \beta$ and $p E 3-A \beta$ accumulate. IsoD- $A \beta$ was largely extracellular, in core plaques as well as in blood vessel walls, in accordance with previous published data $[14,36]$. While the majority of AD cases had both these features, they were less prevalent in the $\mathrm{OC}$ group. In $\mathrm{AD}$, IsoD- $\mathrm{A} \beta$ in core plaques and $\mathrm{CAA}$ was more prevalent than IsoD-A $\beta$ within neurons. This is in agreement with the results of a previous study focused on DS and small group of $\mathrm{AD}$ and $\mathrm{OC}$ with IsoD- $\mathrm{A} \beta$ detected in amyloid cores and vascular amyloid [10]. The limited intraneuronal detection of IsoD-A $\beta$ is consistent with the location in the cytoplasm and endoplasmatic reticulum of L-isoaspartyl methyltransferase, the enzyme able to repair IsoD to L-aspartyl residue. This explains that possibilities to repair extracellular IsoD are very limited [36], implying that once extracellular IsoD-A $\beta$ deposits are formed, differently from intraneuronal deposits, they might likely remain unrepaired.

We detected $\mathrm{pE} 3-\mathrm{A} \beta$ in the vasculature, as previously reported [17, 41], but in our larger cohorts the prevalence of this feature was not significantly greater in $\mathrm{AD}$ than controls. However, $\mathrm{pE} 3-\mathrm{A} \beta$ in $\mathrm{AD}$ was found in diffuse deposits, core plaques and intraneuronal deposits, in agreement with previous studies $[17,45]$ and in these specific locations, $\mathrm{pE} 3-\mathrm{A} \beta$ was significantly more frequent in $\mathrm{AD}$ than $\mathrm{OC}$. Of note, $\mathrm{pE} 3-\mathrm{A} \beta$ in core plaques was the only feature observed in the majority of both $\mathrm{AD}$ and $\mathrm{OC}$. A larger difference in the comparison of $\mathrm{pE} 3-\mathrm{A} \beta$ neuropathological features between $\mathrm{OC}$ and $\mathrm{AD}$ was related to intraneuronal $\mathrm{pE} 3-\mathrm{A} \beta$, which was limited to few $\mathrm{OC}$ cases while present in $52 \%$ of $\mathrm{AD}$. This suggests that intraneuronal accumulation of $\mathrm{pE} 3-\mathrm{A} \beta$ might be characteristic of $\mathrm{AD}$, compatible with an increased somatic activity of $\mathrm{QC}$ enzyme. The presence of $\mathrm{pE} 3-\mathrm{A} \beta$ in plaques, might result instead from the possibility of secretion of this enzyme into the extracellular space, as observed in some experimental studies [7].

Our correlation analyses showed a number of relationships between IsoD and $\mathrm{pE} 3-\mathrm{A} \beta$ and hallmarks of $\mathrm{AD}$. We observed positive associations of IsoD-A $\beta$ with $p E 3-A \beta$ and $A \beta$ (peptide with no $\mathrm{N}$-terminal modifications) in $\mathrm{AD}$. Of note, the same relationships were found in $\mathrm{OC}$, although they had less IsoD-A $\beta$. This suggests that the presence of IsoD is associated with a process of accumulation of $A \beta$ forms, already in progress with ageing. This is 
indeed in agreement with studies showing that isoaspartate post-translational modifications affect the fibrillization and toxicity properties of $A \beta[3]$, possibly with a role in seeding the accumulation of $A \beta$ species [43]. Interestingly in $O C$, both IsoD- and $p E 3-A \beta$ showed associations with $A \beta P P$ and $A \beta$ loads. In $A D$, despite the increased accumulation of IsoD-A $\beta$ and $p E 3-A \beta$, there was no association of the two modified forms with $A \beta P P$ and only IsoD- $A \beta$ correlated with $A \beta$ load, while $p E 3-A \beta$ was independent from it. This may imply that different mechanisms control the accumulation of these $A \beta$ modifications in ageing and in $\mathrm{AD}$, with the existence of a direct link between IsoD-/pE3-A $\beta$ accumulation and $\mathrm{A} \beta \mathrm{PP}$ only during ageing.

p-TAU was associated with pE3-A $\beta$ in both $A D$ and OC cohorts, but not with the same strength as the other described associations. This relationship was already described in a study performed in $18 \mathrm{AD}$ and 23 agematched controls [17], where the data of both cohorts were combined. Accordingly, when we pooled AD and OC data, our association became stronger $(\rho=0.6704$, $p<0.0001$ ) and similar to the previous published study, as shown in Additional file 1: Figure S1. Therefore, it is reasonable to hypothesize that the presence of $\mathrm{pE} 3-\mathrm{A} \beta$ in the brain leads to further neuropathological lesions, like the hyperphosphorylation of tau.

In summary, we have observed that high levels of IsoD- and $\mathrm{pE} 3-\mathrm{A} \beta$ are present in $\mathrm{AD}$ brain. IsoD- $\mathrm{A} \beta$ accumulation appears to be mainly related to ageing and, both in old and AD brains, this modification is associated with the build-up of unmodified $A \beta$ as well as $\mathrm{pE} 3-\mathrm{A} \beta$. In $A D$, IsoD- $A \beta$ load is significantly higher than in $\mathrm{OC}$ and also accumulates significantly more in blood vessel walls. In contrast, $\mathrm{pE} 3-\mathrm{A} \beta$ appears to be more specifically linked to the disease process. In AD brain, $\mathrm{pE} 3-\mathrm{A} \beta$ deposition is significantly higher than in controls with a characteristic location in neurons. However, both post-translational modifications cannot be related at the moment to any temporal sequences of events.

\section{Conclusions}

These findings underline the importance of age-related post-translational modifications of $A \beta$ in relation to $A D$. They complement the studies that have revealed the complexity of $A \beta$ chemistry and activity $[3,15]$. In addition, our observations support the relevance of investigating IsoD- $\mathrm{A} \beta$ and $\mathrm{pE} 3-\mathrm{A} \beta$ levels as potential biomarkers for $\mathrm{AD}$ and the impact of the different $\mathrm{A} \beta$-targeted therapies on these modified forms of $A \beta$. This research could benefit in the future from the development and optimization of new analytical methods [46], able to separate with high resolution the different forms of $A \beta$ peptides in biological fluids.

\section{Additional file}

Additional file 1: Contains all supplemental information mentioned in this manuscript. Table S1. Characteristics of the old control and AD cohorts. Figure S1. Representation of the correlations between $p E 3-A \beta$ and phospho-TAU in OC and AD groups together. (DOC $203 \mathrm{~kb}$ )

\section{Abbreviations \\ AD: Alzheimer's disease; APP: the amyloid precursor protein; A 3 : Amyloid-beta; AßPP: Precursor forms and A $\beta$; CAA: Cerebral amyloid angiopathy; D: Aspartate; E: Glutamate; G: Glycine; H: Histidine; IsoD-Aß: Isoaspartate modified amyloid-beta; OC: Old controls; pE-A $\beta$ : Pyroglutamate modified amyloid-beta; p-TAU: Hyperphosphorylated tau; QC: Glutaminyl cyclase; S: Serine; YC: Young controls}

\section{Acknowledgements}

We would like to thank the different brain Banks and their managers for providing the tissue for this study. This includes: (i) the South West Brain Dementia Brain Bank (SWDBB) which is supported by BRACE (Bristol Research into Alzheimer's and Care of the Elderly), Brains for Dementia Research and the Medical Research Council; (ii) the NHS Greater Glasgow and Clyde Trust as part of the UK Brain Archive Information Network (BRAIN UK) which is funded by the Medical Research Council and brainstrust. We acknowledge the Histochemistry Research Unit and the Biomedical Imaging Unit of the Faculty of Medicine, University of Southampton that facilitated tissue processing, staining and analysis.

\section{Funding}

This work was funded by a Marie Curie Intra European Fellowship within the 7th European Community Framework (Project No: 627152; Project Acronym: AlzProtAgeing, to Dr. Moro) and by the Alzheimer's Research UK (grant ARUK-PG2012-8, to Prof Boche).

Availability of data and materials

The datasets used and/or analysed during the current study are available from the corresponding author on reasonable request.

\section{Authors' contributions}

MLM, AM and DB designed the study. MLM, ASP, KG, CP performed all experiments. JARN provided assistance with the neuropathological assessments; MLM and DB analysed and interpreted the data. MLM wrote the manuscript and DB, JARN and AM reviewed the manuscript. All authors read and approved the final manuscript.

\section{Ethics approval and consent to participate}

The study was covered by the ethical approval from the Brain banks that provided the tissue. The YC cohort was sourced from BRAIN UK (NRES Committee South Central Hampshire B, REC reference: 14/SC/0098), OC and AD cases from the South West Dementia Brain bank (NRES Committee South West Central Bristol, REC reference: 08/H0106/28 + 5). All donors have given informed consent for autopsy and use of their brain tissue for research purposes.

Consent for publication

Not applicable

\section{Competing interests}

The authors declare that they have no competing interests.

\section{Publisher's Note}

Springer Nature remains neutral with regard to jurisdictional claims in published maps and institutional affiliations.

\section{Author details}

${ }^{1}$ Clinical Neurosciences, Clinical and Experimental Sciences Academic Unit, Faculty of Medicine, University of Southampton, Southampton, UK. ${ }^{2}$ Centre for Biological Sciences, Faculty of Natural \& Environmental Sciences, University of Southampton, Southampton, UK. 


\section{Received: 18 November 2017 Accepted: 16 December 2017} Published online: 03 January 2018

\section{References}

1. Aho L, Pikkarainen M, Hiltunen M, Leinonen V, Alafuzoff I (2010) Immunohistochemical visualization of amyloid-beta protein precursor and amyloid-beta in extra- and intracellular compartments in the human brain. J Alzheimers Dis 20:1015-1028. https://doi.org/10.3233/JAD-2010-091681

2. Alafuzoff I, Pikkarainen M, Arzberger T, Thal DR, Al-Sarraj S, Bell J, Bodi I, Budka H, Capetillo-Zarate E, Ferrer I et al (2008) Inter-laboratory comparison of neuropathological assessments of beta-amyloid protein: a study of the BrainNet Europe consortium. Acta Neuropathol 115:533-546. https://doi.org/ 10.1007/s00401-008-0358-2

3. Fossati S, Todd K, Sotolongo K, Ghiso J, Rostagno A (2013) Differential contribution of isoaspartate post-translational modifications to the fibrillization and toxic properties of amyloid beta and the Asn23 lowa mutation. Biochem J 456:347-360. https://doi.org/10.1042/BJ20130652

4. Frost JL, Liu B, Rahfeld JU, Kleinschmidt M, O'Nuallain B, Le KX, Lues I, Caldarone BJ, Schilling S, Demuth HU et al (2015) An anti-pyroglutamate-3 Abeta vaccine reduces plaques and improves cognition in APPswe/ PS1DeltaE9 mice. Neurobiol Aging 36:3187-3199. https://doi.org/10.1016/j. neurobiolaging.2015.08.021

5. Gouras GK, Tsai J, Naslund J, Vincent B, Edgar M, Checler F, Greenfield JP, Haroutunian V, Buxbaum JD, Xu H et al (2000) Intraneuronal Abeta42 accumulation in human brain. Am J Pathol 156:15-20

6. Grabowski TJ, Cho HS, Vonsattel JP, Rebeck GW, Greenberg SM (2001) Novel amyloid precursor protein mutation in an lowa family with dementia and severe cerebral amyloid angiopathy. Ann Neurol 49:697-705

7. Hartlage-Rubsamen M, Morawski M, Waniek A, Jager C, Zeitschel U, Koch B, Cynis H, Schilling S, Schliebs R, Demuth HUet al (2011) Glutaminyl cyclase contributes to the formation of focal and diffuse pyroglutamate (pGlu)Abeta deposits in hippocampus via distinct cellular mechanisms. Acta Neuropathol 121: 705-719 https://doi.org/10.1007/s00401-011-0806-2

8. Horikoshi Y, Sakaguchi G, Becker AG, Gray AJ, Duff K, Aisen PS, Yamaguchi H, Maeda M, Kinoshita N, Matsuoka Y (2004) Development of Abeta terminal endspecific antibodies and sensitive ELISA for Abeta variant. Biochem Biophys Res Commun 319:733-737. https://doi.org/10.1016/j.bbrc.2004.05.051

9. Inoue K, Hosaka D, Mochizuki N, Akatsu H, Tsutsumiuchi K, Hashizume Y, Matsukawa N, Yamamoto T, Toyo'oka T (2014) Simultaneous determination of post-translational racemization and isomerization of $\mathrm{N}$-terminal amyloidbeta in Alzheimer's brain tissues by covalent chiral derivatized ultraperformance liquid chromatography tandem mass spectrometry. Anal Chem 86:797-804. https://doi.org/10.1021/ac403315h

10. Iwatsubo T, Saido TC, Mann DM, Lee VM, Trojanowski JQ (1996) Full-length amyloid-beta (1-42(43)) and amino-terminally modified and truncated amyloid-beta 42(43) deposit in diffuse plaques. Am J Pathol 149:1823-1830

11. Jawhar S, Wirths O, Bayer TA (2011) Pyroglutamate amyloid-beta (Abeta): a hatchet man in Alzheimer disease. J Biol Chem 286:38825-38832. https:// doi.org/10.1074/jbc.R111.288308

12. Kovacs GG, Lutz MI, Ricken G, Strobel T, Hoftberger R, Preusser M, Regelsberger G, Honigschnabl S, Reiner A, Fischer P et al (2016) Dura mater is a potential source of Abeta seeds. Acta Neuropathol 131:911-923. https:// doi.org/10.1007/s00401-016-1565-x

13. Kuge K, Kitamura K, Nakaoji K, Hamada K, Fujii N, Saito T, Fujii N (2010) Oxidative stress induces the formation of D-aspartyl residues in the elastin mimic peptides. Chem Biodivers 7:1408-1412. https://doi.org/10.1002/cbdv. 200900348

14. Kummer MP, Heneka MT (2014) Truncated and modified amyloid-beta species. Alzheimers Res Ther 6:28. https://doi.org/10.1186/alzrt258

15. Lee J, Gillman AL, Jang H, Ramachandran S, Kagan BL, Nussinov R, Teran Arce $F$ (2014) Role of the fast kinetics of pyroglutamate-modified amyloidbeta oligomers in membrane binding and membrane permeability. Biochemistry 53:4704-4714. https://doi.org/10.1021/bi500587p

16. Lemere CA, Blusztajn JK, Yamaguchi H, Wisniewski T, Saido TC, Selkoe DJ (1996) Sequence of deposition of heterogeneous amyloid beta-peptides and APO E in down syndrome: implications for initial events in amyloid plaque formation. Neurobiol Dis 3:16-32. https://doi.org/10.1006/nbdi.1996.0003

17. Mandler M, Walker L, Santic R, Hanson P, Upadhaya AR, Colloby SJ, Morris CM, Thal DR, Thomas AJ, Schneeberger A et al (2014) Pyroglutamylated amyloidbeta is associated with hyperphosphorylated tau and severity of Alzheimer's disease. Acta Neuropathol 128:67-79. https://doi.org/10.1007/s00401-014-1296-9
18. McGrath LT, McGleenon BM, Brennan S, McColl D, Mc IS, Passmore AP (2001) Increased oxidative stress in Alzheimer's disease as assessed with 4hydroxynonenal but not malondialdehyde. QJM 94:485-490

19. Meissner JN, Bouter $Y$, Bayer TA (2015) Neuron loss and behavioral deficits in the TBA42 mouse model expressing $\mathrm{N}$-truncated Pyroglutamate Amyloidbeta3-42. J Alzheimers Dis 45:471-482. https://doi.org/10.3233/jad-142868

20. Morawski M, Schilling S, Kreuzberger M, Waniek A, Jager C, Koch B, Cynis H, Kehlen A, Arendt T, Hartlage-Rubsamen M et al (2014) Glutaminyl cyclase in human cortex: correlation with (pGlu)-amyloid-beta load and cognitive decline in Alzheimer's disease. J Alzheimers Dis 39:385-400. https://doi.org/10.3233/ jad-131535

21. Moro ML, Collins MJ, Cappellini E (2010) Alzheimer's disease and amyloid beta-peptide deposition in the brain: a matter of 'aging'? Biochem Soc Trans 38:539-544. https://doi.org/10.1042/bst0380539

22. Nussbaum JM, Schilling S, Cynis H, Silva A, Swanson E, Wangsanut T, Tayler K, Wiltgen B, Hatami A, Ronicke R et al (2012) Prion-like behaviour and taudependent cytotoxicity of pyroglutamylated amyloid-beta. Nature 485:651-655. https://doi.org/10.1038/nature11060

23. Orpiszewski J, Schormann N, Kluve-Beckerman B, Liepnieks JJ, Benson MD (2000) Protein aging hypothesis of Alzheimer disease. FASEB J 14:1255-1263

24. Pascoal TA, Mathotaarachchi S, Shin M, Benedet AL, Mohades S, Wang S, Beaudry T, Kang MS, Soucy JP, Labbe Aet al (2016) Synergistic interaction between amyloid and tau predicts the progression to dementia. Alzheimers Dement https://doi.org/10.1016/j.jalz.2016.11.005

25. Reissner KJ, Aswad DW (2003) Deamidation and isoaspartate formation in proteins: unwanted alterations or surreptitious signals? Cell Mol Life Sci 60: 1281-1295. https://doi.org/10.1007/s00018-003-2287-5

26. Rijal Upadhaya A, Kosterin I, Kumar S, von Arnim CA, Yamaguchi H, Fandrich M, Walter J, Thal DR (2014) Biochemical stages of amyloid-beta peptide aggregation and accumulation in the human brain and their association with symptomatic and pathologically preclinical Alzheimer's disease. Brain 137:887-903. https://doi.org/10.1093/brain/awt362

27. Rosen RF, Tomidokoro Y, Farberg AS, Dooyema J, Ciliax B, Preuss TM, Neubert TA, Ghiso JA, LeVine H 3rd, Walker LC (2016) Comparative pathobiology of beta-amyloid and the unique susceptibility of humans to Alzheimer's disease. Neurobiol Aging 44:185-196. https://doi.org/10.1016/j. neurobiolaging.2016.04.019

28. Russo C, Violani E, Salis S, Venezia V, Dolcini V, Damonte G, Benatti U, D'Arrigo C, Patrone E, Carlo P et al (2002) Pyroglutamate-modified amyloid beta-peptides-AbetaN3(pE)-strongly affect cultured neuron and astrocyte survival. J Neurochem 82:1480-1489

29. Schenk, D. B. B.. 2011. PREVENTION AND TREATMENT OF AMYLOIDOGENIC DISEASES. United States patent application 20110177066 CA, US

30. Schenk, D. B.; Bard, F.; Yednock, T. 2004. HUMANIZED AND CHIMERIC NTERMINAL AMYLOID BETA-ANTIBODIES. United States patent application 20046750324

31. Schlenzig D, Ronicke R, Cynis H, Ludwig HH, Scheel E, Reymann K, Saido T, Hause G, Schilling S, Demuth HU (2012) N-terminal pyroglutamate formation of Abeta38 and Abeta40 enforces oligomer formation and potency to disrupt hippocampal long-term potentiation. J Neurochem 121 : 774-784 https://doi.org/10.1111/j.1471-41592012.07707x

32. Selkoe DJ (2011) Alzheimer's disease. Cold Spring Harb Perspect Biol 3. https://doi.org/10.1101/cshperspect.a004457

33. Selkoe DJ (2004) Cell biology of protein misfolding: the examples of Alzheimer's and Parkinson's diseases. Nat Cell Biol 6:1054-1061. https://doi. org/10.1038/ncb1104-1054

34. Selkoe DJ, Hardy J (2016) The amyloid hypothesis of Alzheimer's disease at 25 years. EMBO Mol Med 8:595-608. https://doi.org/10.15252/emmm. 201606210

35. Serrano-Pozo A, Frosch MP, Masliah E, Hyman BT (2011) Neuropathological alterations in Alzheimer disease. Cold Spring Harb Perspect Med 1:a006189. https://doi.org/10.1101/cshperspect.a006189

36. Shimizu T, Matsuoka Y, Shirasawa T (2005) Biological significance of isoaspartate and its repair system. Biol Pharm Bull 28:1590-1596

37. Shimizu T, Watanabe A, Ogawara M, Mori H, Shirasawa T (2000) Isoaspartate formation and neurodegeneration in Alzheimer's disease. Arch Biochem Biophys 381:225-234. https://doi.org/10.1006/abbi.2000.1955

38. Sofola-Adesakin O, Khericha M, Snoeren I, Tsuda L, Partridge L (2016) pGluAbeta increases accumulation of Abeta in vivo and exacerbates its toxicity. Acta Neuropathol Commun 4:109. https://doi.org/10.1186/s40478016-0380-x 
39. Takahashi RH, Nagao T, Gouras GK (2017) Plaque formation and the intraneuronal accumulation of beta-amyloid in Alzheimer's disease. Pathol Int 67:185-193. https://doi.org/10.1111/pin.12520

40. Tambo K, Yamaguchi T, Kobayashi K, Terauchi E, Ichi I, Kojo S (2013) Racemization of the aspartic acid residue of amyloid-beta peptide by a radical reaction. Biosci Biotechnol Biochem 77:416-418. https://doi.org/10. 1271/bbb.120797

41. Tekirian TL, Saido TC, Markesbery WR, Russell MJ, Wekstein DR, Patel E, Geddes JW (1998) N-terminal heterogeneity of parenchymal and cerebrovascular Abeta deposits. J Neuropathol Exp Neurol 57:76-94

42. Wakutani Y, Watanabe K, Adachi Y, Wada-Isoe K, Urakami K, Ninomiya H, Saido TC, Hashimoto T, Iwatsubo T, Nakashima K (2004) Novel amyloid precursor protein gene missense mutation (D678N) in probable familial Alzheimer's disease. J Neurol Neurosurg Psychiatry 75:1039-1042

43. Walker LC, Diamond MI, Duff KE, Hyman BT (2013) Mechanisms of protein seeding in neurodegenerative diseases. JAMA Neurology 70:304-310. https://doi.org/10.1001/jamaneurol.2013.1453

44. Warner CJ, Dutta S, Foley AR, Raskatov JA (2016) Introduction of dglutamate at a critical residue of Abeta42 stabilizes a Prefibrillary aggregate with enhanced toxicity. Chemistry 22:11967-11970. https://doi.org/10.1002/ chem.201601763

45. Wirths O, Erck C, Martens H, Harmeier A, Geumann C, Jawhar S, Kumar S, Multhaup G, Walter J, Ingelsson M et al (2010) Identification of low molecular weight pyroglutamate a\{beta\} oligomers in Alzheimer disease: a novel tool for therapy and diagnosis. J Biol Chem 285:41517-41524. https://doi.org/10.1074/jbc.M110.178707

46. Zheng X, Deng L, Baker ES, Ibrahim YM, Petyuk VA, Smith RD (2017) Distinguishing $\mathrm{d}$ - and $\mathrm{l}$-aspartic and isoaspartic acids in amyloid beta peptides with ultrahigh resolution ion mobility spectrometry. Chem Commun 53:7913-7916. https://doi.org/10.1039/c7cc03321d

\section{Submit your next manuscript to BioMed Central and we will help you at every step:}

- We accept pre-submission inquiries

- Our selector tool helps you to find the most relevant journal

- We provide round the clock customer support

- Convenient online submission

- Thorough peer review

- Inclusion in PubMed and all major indexing services

- Maximum visibility for your research

Submit your manuscript at www.biomedcentral.com/submit
Biomed Central 